\title{
SUSCEPTIBILITY TO DOWNY MILDEW (PLASMOPARA VITICOLA) AND POWDERY MILDEW (ERYSIPHE NECATOR) OF DIFFERENT VITIS CULTIVARS AND GENOTYPES
}

\section{SUSCETIBILIDADE AO MÍLDIO (PLASMOPARA VITÍCOLA) E OÍDIO (ERYSIPHE NECATOR) DE DIFERENTES VITIS CULTIVARES E GENÓTIPOS}

\author{
Arif Atak ${ }^{*}$, M. Akkurt ${ }^{2}$, Z. Polat ${ }^{3}$, H.Çelik ${ }^{4}$, K. A. Kahraman ${ }^{1}$, D. S. Akgül ${ }^{5}$, N. Özer ${ }^{6}$, G. Söylemezoğlu ${ }^{2}$ G. \\ G. Şire ${ }^{1}$, R. Eibach ${ }^{7}$
}

${ }^{1}$ Department of Viticulture, Ataturk Horticultural Central Research Institute, 77102 Yalova, Turkey.
${ }_{2}^{2}$ Department of Horticulture, Agriculture Faculty, Ankara University, Ankara, Turkey.
${ }^{3}$ Department of Plant Protection, Ataturk Horticultural Central Research Institute, 77102 Yalova, Turkey.
${ }^{4}$ Department of Horticulture, Agriculture Faculty, Ondokuzmayıs University, Samsun, Turkey.
${ }^{5}$ Department of Plant Protection, Agriculture Faculty, Çukurova University, Adana, Turkey.
${ }^{6}$ Department of Plant Protection, Agriculture Faculty, Namik Kemal University, Tekirdağ, Turkey.
${ }^{7}$ Julius Kühn-Institut, Institute for Grapevine Breeding Geilweilerhof, Siebeldingen, Germany.

*corresponding author: Tel: +90 226814252 (ex 1220), +90 226505 4804130; email: atakarif@gmail.com

(Received 06.09.2016. Accepted 18.03.2017)

SUMMARY

Turkey has a very old history of viticulture and also homeland of the grapevine (Vitis spp.). Vitis cultivars belonging to different species are grown in almost every region in the country. However, particularly downy mildew and powdery mildew diseases affect the cultivars belonging to Vitis vinifera. In northern of Turkey Vitis labrusca and hybrids between V.vinifera and V.labrusca are rather common. V.labrusca cultivars or genotypes exhibit generally higher degree of resistance than $V$. vinifera cultivars. However, resistance level can vary from cultivar to cultivar and even from clone to clone within one cultivar. In this study, different Vitis hybrids and genotypes which exhibit different downy and powdery mildew susceptibility are compared for two years. Especially some V.labrusca hybrids and genotypes appeared resistance for both diseases. On the other hand, interspecific crosses and V.vinifera cultivars were found to be more susceptible. Using resistant lines as parent in later breeding activities, it could be possible grow high quality table cultivars with much fewer pesticide applications or possibly without them.

\section{RESUMO}

A Turquia tem uma longa história vitícola, sendo inclusivé um dos pontos de origem da videira (Vitis spp.). As diferentes espécies de Vitis são cultivadas em quase todas as regiões do país. Doenças como o míldio e oídio afetam em particular as videiras pertencentes à espécie V.vinifera. No Norte da Turquia, as espécies Vitis labrusca e híbridos entre V. vinifera e V. labrusca são bastante comuns. As cultivares/genótipos de V. labrusca exibem um grau de resistência geralmente mais elevado do que as cultivares de $V$. vinifera. No entanto o nível de resistência pode variar de cultivar para cultivar e até mesmo de clone para clone dentro de uma mesma cultivar. Neste estudo foram comparados diferentes híbridos de Vitis e genótipos com diferentes suscetibilidades ao míldio e ao oídio por um período de dois anos. Alguns híbridos e genótipos de V.labrusca apresentaram resistência a ambas as doenças. Por outro lado, os cruzamentos interespecíficos e as cultivares de V.vinifera foram identificados como sendo mais susceptíveis. Usando linhas resistentes como linha parental em atividades de melhoramento posteriores, poderia ser possível desenvolver cultivares para produção de vinhos de mesa de alta qualidade com menores exigências de aplicações de pesticidas ou possivelmente sem eles.

Key words: Vitis spp., fungal diseases, inoculation, resistant, natural infection.

Palavras-chave: Vitis spp, doenças fúngicas, inoculação, resistência, infecção natural.

\section{INTRODUCTION}

Grape is cultivated over an area of 7.100.000 hectares with an annual production of 77.000 .000 tonnes in the world. Turkey has 460.000 hectares of vineyard area and produces approximately 4.000 .000 tonnes (FAO, 2015). In Turkey 52\% of the production is used as table grape. Turkey is one of the top producer of

This is an Open Access article distributed under the terms of the Creative Commons Attribution License (http://creativecommons.org/licenses/by/4.0), which permits unrestricted use, distribution, and reproduction in any medium, provided the original work is properly cited. 
grape and takes second place in table grape production in the world (TUIK, 2015).

Downy mildew (Plasmopara viticola) and powdery mildew (Erysiphe necator) are the most devastating diseases of grapes around the world. Especially they cause yield and quality loss in humid regions. Not only table grapes but also most of the wine grapes are damaged by both diseases. A large number of fungicide applications are needed in order to produce high quality grape. This situation leads to serious problems for human health. The reduction of pesticides is highly desirable for environmental protection, human health, and food safety (Hoffmann et al., 2007; Deliere et al., 2010; Riaz et al., 2011).

There are great differences in susceptibility within Vitis species to fungal diseases. Several Vitis species and interspecific crosses have high resistance to many fungal diseases. For example, V.vinifera is considered highly susceptible, whereas the American species, such as $V$. labrusca, $V$. riparia and $V$. rupestris are much less susceptible. However, species and cultivars differ in their susceptibility to diseases (Wan et al., 2007). Grapes might be successfully grown without spraying chemicals if naturally resistant and high quality cultivars are bred and selected. In recent years different breeding studies have been carried out to obtain downy and powdery mildew resistant or tolerant cultivars (Hajdu, 2007; Cindric et al., 2009; Lisek, 2014).

However, between selected cultivars the degree of resistance can vary considerably. Different resistance levels can be also due to different pathogen races, severity of disease or ecology in different locations. Also, the severity of diseases varies from year to year, depending primarily on weather conditions, the presence of inoculum (history of the disease) and the susceptibility of the vines (Carisse et al., 2006; CadleDavidson, 2008). Therefore, it will be the right approach to analyse resistant levels of cultivars in different ecologies. Some cultivars or accessions obtained by selection and hybridization were used in this study. The objective of this study is to compare downy mildew and powdery mildew resistance levels of different grape cultivars or genotypes which obtained by selection and hybridization. Especially accessions belonging to V labrusca collected from northern Turkey are primarily screened for disease resistance. Moreover, a final goal was to determine cultivars/genotypes that could be successfully grown with reduced fungicide application, or possibly without them.

\section{MATERIAL AND METHODS}

\section{Plant material}

35 different grape cultivars/genotypes were used in this study. 26 Vitis labrusca genotypes considering to be resistant against fungal diseases constitute the main source of this study. These accessions were collected from north of the Turkey especially Black Sea coastline. In addition to these $V$. labrusca genotypes six inter-species hybrid grape cultivars which may be considered resistant in terms of downy and powdery mildew. Finally, three different Vitis vinifera cultivars are used for comparison. The Vitis vinifera $c v$. Italia is particularly used as a susceptible control since it is known to be highly susceptible to fungal diseases especially powdery mildew.

\section{Natural infections}

The experiments were carried out according to common procedures and no pesticides were carried out in the experimental areas. Natural vineyard conditions were supplied in the experimental area so infected leaves and shoots were distributed randomly within the plants in order to provide sufficient inoculation. All vines were potted (minimum three plants per cultivar) and suspended to natural infection. The natural infection evaluation was carried out on leaves and clusters during June, July and August.

\section{Inoculation for powdery mildew}

All vines were planted in pots and cultivated in the greenhouse for Inoculations (minimum three plants per variety). For inoculation the modified method of Wang et al. (1995) was applied. Fungal conidia were collected from infected leaves, washed with $0,78 \%$ glucose solution, imitating the osmotic pressure of powdery mildew conidia and then suspended in sterile water. Vine leaves were inoculated with the conidial suspension at the rate of $2 \times 10^{5}$ conidia $/ \mathrm{mL}$ by spraying the upper surface of the leaves. Inoculated leaves were immediately covered by thin plastic for 6 hours.

\section{Inoculation for downy mildew}

The method of Rumbolz et al. (2002) and Boso et al. (2006) were used to propagate sporangia inoculum. Plasmopara viticola was obtained from naturally infected plants in the vineyards of the Atatürk Horticulture Central Research Institute Yalova, Turkey and Çukurova University Agriculture Faculty Adana, Turkey. For the propagation of the inoculum, plants were sprayed with a suspension of sporangia (40,000 sporangia $\mathrm{mL}^{-1}$ distilled water) on the abaxial leaf side and whole plants were covered with a polyethylene cover during night. On following day, 
the polyethylene covers were removed and incubation lasted 5-6 days at 25-26 ${ }^{\circ} \mathrm{C}$. The same inoculation procedure was repeated after 5-6 days.

\section{Evaluation of powdery mildew natural infection and inoculation of leaves}

For disease evaluation, 4 young leaves from the top were selected from each vine (several plants) and were examined at different times during JuneAugust. The infection severity on leaves was determined based on per cent of disease spots observed on the entire leaf area according to the procedure described by Table I (GENRES-081, 1997). Disease severity was evaluated 3 weeks after inoculation.

\section{Table I}

Rating levels for oidium infection of leaves of genotypes for their degree of resistance to powdery mildew under the same conditions.

Níveis de avaliação para a infecção por oídio das folhas de genótipos e seu grau de resistência ao oídio nas mesmas condições.

\begin{tabular}{cl}
\hline Level & \multicolumn{1}{c}{ Symptoms } \\
\hline 1 & $\begin{array}{l}\text { Very low (tiny spots or no symptoms; neither visible } \\
\text { sporulation nor mycelium) } \\
\text { Low (limited patches }<2 \mathrm{~cm} \text { diameter; limited } \\
\text { sporulation and mycelium; the presence of Uncinula is } \\
\text { only indicated by a slight curling of the blade }\end{array}$ \\
5 & $\begin{array}{l}\text { Medium (patches usually limited with a diameter of 2-5 } \\
\text { cm) }\end{array}$ \\
7 & $\begin{array}{l}\text { High (vast patches; some limited; strong sporulation } \\
\text { and abundant mycelium) } \\
\text { Very high (very vast unlimited patches or totally } \\
\text { attached leaf blades; strong sporulation and abundant } \\
\text { mycelium) }\end{array}$ \\
\hline
\end{tabular}

\section{Evaluation of downy mildew natural infection and inoculation of leaves}

For disease evaluation, all leaves of each plant was evaluated for downy mildew at different times during May-August. The infection severity on leaves was determined based on per cent of disease spots observed on the entire leaf area according to the procedure described by Table II (GENRES-081, 1997).

\section{Disease assessments and statistical analysis}

Scoring was done primarily to determine the response of plants to disease during the two growing season. Different methods and number of leaves are selected for each disease. When all leaves of each pot evaluated for downy mildew but only first 4 young leaves of each vines evaluated. Disease severity estimated as the percentage of affected leaves. Disease severity (infection degree, ID) was computed using a scale of total number of classes with the Townsend-Heuberger formula (TownsendHeuberger, 1943): ID $(\%)=\Sigma \mathrm{i} 1(n i \times v i) / N \times V$ where $v i$ is the damage class, $n i$ is the number in one class, $N$ is the total number, $V$ is the highest class, $\mathrm{i}$ is the number of classes.

\section{Table II}

Rating levels for infection of leaves of genotypes for their degree of resistance to downy mildew under the same conditions.

Níveis de avaliação para a infecção de folhas de genótipos e seu grau de resistência ao míldio, nas mesmas condições.

\begin{tabular}{cl}
\hline Level & \multicolumn{1}{c}{ Symptoms } \\
\hline 1 & $\begin{array}{l}\text { Very low (tiny necrotic spots or no symptoms; neither } \\
\text { sporulation nor mycelium) }\end{array}$ \\
3 & $\begin{array}{l}\text { Low (small patches }<1 \mathrm{~cm} \text { in diameter; little sporulation } \\
\text { or mycelium }\end{array}$ \\
5 & $\begin{array}{l}\text { Medium (little patches } 1-2 \mathrm{~cm} \text { diameter; more or less } \\
\text { strong sporulation; irregular formation of mycelium) }\end{array}$ \\
7 & $\begin{array}{l}\text { High ( vast patches; strong sporulation and abundant } \\
\text { mycelium; leaf drop later than below) } \\
\text { Very high (vast patches or totally attached leaf blades; } \\
\text { strong sporulation and dense mycelium; very early leaf } \\
\text { drop) }\end{array}$ \\
\hline
\end{tabular}

Downy mildew resistance level of each cultivar was rated based on its Severity index (SI: ER) (Staudt and Kassemeyer, 1995):

- $\quad$ ER, Extremely Resistant, SI: 0-5.0

- HR, Highly Resistant, SI: 5.1-25

- $\quad$ R, Resistant, SI: 25.1-50

- $\quad$ S, Susceptible, SI: 50.1-75

- $\quad$ HS, Highly Susceptible, SI: $>75.1$

Powdery mildew resistance level of each cultivar was rated based on its Severity Index (SI: ER):

- $\quad$ ER, Extremely Resistant, SI = 0

- $\quad$ HR, Highly Resistant, $\mathrm{SI}=0.1-5.0$

- $\quad \mathrm{R}$, Resistant, $\mathrm{SI}=5.1-25.0$

- $\quad \mathrm{S}$, Susceptible, SI = 25.1 - 50

- $\quad$ HS, Highly susceptible, SI = 50.1 - 100

Each variant was examined by analysis of variance to determine significant differences among accessions. Also they were analysed randomized experimental design analysis of variance with three replicates also repeated two years. For each variant, LSMeans differences Student's test (minimum significant difference method) was used to determine the level of resistance for all accessions. Duncan's multiple range test was used to compare infections. Differences at $\mathrm{p}<0.05$ were considered to be significant. Pearson's correlation coefficient (R) was used to evaluate covariance relationships between variables. All 
calculations were performed using JMP 7.0 software (SAS, 2007).

\section{RESULTS AND DISCUSSION}

Average of the experiments in the reactions of different cultivars/genotypes to downy and powdery mildew diseases during 2014 and 2015 are shown in Tables III and IV. During June and July climate parameters in 2014 and 2015 are quite similar. In 2014, during June and July the average temperature was $22-26{ }^{\circ} \mathrm{C}$ and relative humidity was $75 \%$. In 2015, during June and July the average temperature was $21.5-25^{\circ} \mathrm{C}$ and relative humidity $75 \%$ (Figure 1 and Figure 2). Climatic conditions have also been very suitable for both diseases.

Table III

Disease severity of accessions for downy mildew

Gravidade da doença em função da exposição ao míldio

\begin{tabular}{|c|c|c|c|c|c|}
\hline \multirow{2}{*}{ Accessions } & \multirow{2}{*}{ Species } & \multicolumn{2}{|c|}{ Natural Infection } & \multicolumn{2}{|c|}{ Inoculation } \\
\hline & & Average (\%) & Severity Index & Average (\%) & Severity Index \\
\hline 57 Ayancık 01 & V.labrusca & $1^{\mathrm{i}}$ & ER & $14^{\mathrm{c}-\mathrm{i}}$ & HR \\
\hline 57 Erfelek 03 & V.labrusca & $2^{\mathrm{i}}$ & ER & $5^{\mathrm{ij}}$ & ER \\
\hline 57 Gerze 04 & V.labrusca & $0^{\mathrm{i}}$ & ER & $11^{\mathrm{d}-\mathrm{j}}$ & HR \\
\hline 61 Of 04 & V.labrusca & $3^{\mathrm{g}-\mathrm{i}}$ & ER & $20^{\mathrm{cd}}$ & HR \\
\hline 61 Sürmene 01 & V.labrusca & $15^{\mathrm{b}-\mathrm{e}}$ & HR & $10^{\mathrm{d}-\mathrm{j}}$ & HR \\
\hline 61 Sürmene 02 & V.labrusca & $4^{g-i}$ & ER & $11^{\mathrm{d}-\mathrm{j}}$ & HR \\
\hline 61 Yomra 04 & V.labrusca & $11^{\mathrm{b}-\mathrm{h}}$ & HR & $4^{\mathrm{j}}$ & ER \\
\hline 53 Merkez 02 & V.labrusca & $25^{\mathrm{a}}$ & HR & $39^{\mathrm{ab}}$ & $\mathrm{R}$ \\
\hline Rizessi & V.labrusca & $0^{\mathrm{a}}$ & ER & $16^{\mathrm{c}-\mathrm{g}}$ & HR \\
\hline Rizpem & V.labrusca & $4^{\mathrm{g}-\mathrm{i}}$ & ER & $9^{e-j}$ & HR \\
\hline Çeliksu & V.labrusca & $9^{d-i}$ & HR & $5^{\mathrm{h}-\mathrm{j}}$ & ER \\
\hline Rizellim & V.labrusca & $4^{\mathrm{g}-\mathrm{i}}$ & ER & $18^{\mathrm{c}-\mathrm{f}}$ & HR \\
\hline 55 Merkez 06 & V.labrusca & $7^{\mathrm{e}-\mathrm{i}}$ & HR & $19^{\mathrm{c}-\mathrm{e}}$ & HR \\
\hline 55 Merkez 12 & V.labrusca & $5^{\mathrm{f}-\mathrm{i}}$ & ER & $16^{\mathrm{c}-\mathrm{g}}$ & HR \\
\hline 53 Güneysu 01 & V.labrusca & $4^{g-i}$ & ER & $7^{\mathrm{g}-\mathrm{j}}$ & HR \\
\hline Ülkemiz & V.labrusca & $0^{\mathrm{i}}$ & ER & $4^{j}$ & ER \\
\hline 53 Pazar 02 & V.labrusca & $15^{\mathrm{b}-\mathrm{e}}$ & HR & $19^{\mathrm{c}-\mathrm{e}}$ & HR \\
\hline 55 Çarşamba 01 & V.labrusca & $4^{\mathrm{g}-\mathrm{i}}$ & ER & $6^{g-j}$ & HR \\
\hline 28 Tirebolu 02 & V.labrusca & $4^{g-i}$ & ER & $8^{\mathrm{f}-\mathrm{j}}$ & HR \\
\hline 28 Görele 01 & V.labrusca & $3^{g-i}$ & ER & $4^{\mathrm{j}}$ & ER \\
\hline 28 Merkez 01 & V.labrusca & $1^{\mathrm{i}}$ & ER & $15^{\mathrm{c}-\mathrm{j}}$ & HR \\
\hline 55 Merkez 09 & V.labrusca & $0^{\mathrm{i}}$ & ER & $5^{\mathrm{h}-\mathrm{j}}$ & ER \\
\hline 57 Gerze 01 & V.labrusca & $0^{\mathrm{i}}$ & ER & $8^{\mathrm{f}-\mathrm{j}}$ & HR \\
\hline 57 Merkez 07 & V.labrusca & $2^{\text {hi }}$ & ER & $2^{\mathrm{j}}$ & ER \\
\hline Isabella (Yalova) & V.labrusca & $2^{\text {hi }}$ & ER & $10^{d-j}$ & HR \\
\hline Isabella (Tekirdağ) & V.labrusca & $14^{\mathrm{b}-\mathrm{f}}$ & HR & $8^{\mathrm{f}-\mathrm{j}}$ & HR \\
\hline Steuben & Interspecific cross & $9^{d-i}$ & HR & $2^{j}$ & ER \\
\hline Kyoho & Interspecific cross & $6^{\mathrm{e}-\mathrm{i}}$ & HR & $24^{\mathrm{c}}$ & HR \\
\hline Edelweiss & Interspecific cross & $7^{\mathrm{e}-\mathrm{i}}$ & HR & $9^{e-j}$ & HR \\
\hline Sheridan & Interspecific cross & $14^{\mathrm{b}-\mathrm{f}}$ & HR & $4^{\mathrm{ij}}$ & ER \\
\hline Glenora (Seedless) & Interspecific cross & $12^{\mathrm{b}-\mathrm{g}}$ & HR & $10^{\mathrm{d}-\mathrm{j}}$ & HR \\
\hline Himrod (Seedless) & Interspecific cross & $14^{\mathrm{b}-\mathrm{f}}$ & HR & $9^{e-j}$ & HR \\
\hline Autumn Royal (Seedless) & Vitis vinifera & $17^{\mathrm{a}-\mathrm{d}}$ & HR & $38^{\mathrm{b}}$ & $\mathrm{R}$ \\
\hline Red Globe & Vitis vinifera & $9^{d-i}$ & HR & $49^{\mathrm{a}}$ & $\mathrm{R}$ \\
\hline Italia & Vitis vinifera & $20^{\mathrm{ab}}$ & HR & $40^{\mathrm{ab}}$ & $\mathrm{R}$ \\
\hline
\end{tabular}


Table IV

Disease severity of accessions for powdery mildew

Gravidade da doença em função da exposição ao oídio

\begin{tabular}{|c|c|c|c|c|c|}
\hline \multirow{2}{*}{ Accessions } & \multirow{2}{*}{ Species } & \multicolumn{2}{|c|}{ Natural Infection } & \multicolumn{2}{|c|}{ Inoculation } \\
\hline & & Average (\%) & Severity Index & Average (\%) & Severity Index \\
\hline 57 Ayancık 01 & V.labrusca & $0^{j}$ & ER & $11^{\mathrm{h}-1}$ & $\mathrm{R}$ \\
\hline 57 Erfelek 03 & V.labrusca & $14^{\mathrm{g}-\mathrm{j}}$ & $\mathrm{R}$ & $31^{\mathrm{b}-\mathrm{f}}$ & $\mathrm{S}$ \\
\hline 57 Gerze 04 & V.labrusca & $0^{\mathrm{j}}$ & ER & $39^{\mathrm{b}-\mathrm{d}}$ & $\mathrm{S}$ \\
\hline 61 Of 04 & V.labrusca & $5^{h-j}$ & HR & $20^{\mathrm{e}-\mathrm{k}}$ & $\mathrm{R}$ \\
\hline 61 Sürmene 01 & V.labrusca & $0^{\mathrm{j}}$ & ER & $29^{\mathrm{c}-\mathrm{h}}$ & $\mathrm{S}$ \\
\hline 61 Sürmene 02 & V.labrusca & $1^{\mathrm{ij}}$ & $\mathrm{HR}$ & $1^{1}$ & HR \\
\hline 61 Yomra 04 & V.labrusca & $14^{\mathrm{g}-\mathrm{j}}$ & $\mathrm{R}$ & $4^{\mathrm{k} 1}$ & HR \\
\hline 53 Merkez 02 & V.labrusca & $7^{\mathrm{h}-\mathrm{j}}$ & $\mathrm{R}$ & $24^{\mathrm{d}-\mathrm{i}}$ & $\mathrm{R}$ \\
\hline Rizessi & V.labrusca & $5^{\mathrm{h}-\mathrm{j}}$ & HR & $23^{\mathrm{d}-\mathrm{j}}$ & $\mathrm{R}$ \\
\hline Rizpem & V.labrusca & $2^{\mathrm{ij}}$ & $\mathrm{HR}$ & $12^{\mathrm{g}-1}$ & $\mathrm{R}$ \\
\hline Çeliksu & V.labrusca & $4^{\mathrm{ij}}$ & $\mathrm{HR}$ & $27^{\mathrm{c}-\mathrm{h}}$ & $\mathrm{S}$ \\
\hline Rizellim & V.labrusca & $33^{\text {de }}$ & $\mathrm{S}$ & $37^{\mathrm{b}-\mathrm{e}}$ & $\mathrm{S}$ \\
\hline 55 Merkez 06 & V.labrusca & $0^{\mathrm{j}}$ & ER & $4^{\mathrm{kl}}$ & HR \\
\hline 55 Merkez 12 & V.labrusca & $6^{\mathrm{h}-\mathrm{j}}$ & $\mathrm{R}$ & $0^{1}$ & ER \\
\hline 53 Güneysu 01 & V.labrusca & $0^{\mathrm{j}}$ & ER & $15^{\mathrm{f}-1}$ & $\mathrm{R}$ \\
\hline Ülkemiz & V.labrusca & $33^{\mathrm{df}}$ & $\mathrm{S}$ & $18^{\mathrm{f}-1}$ & $\mathrm{R}$ \\
\hline 53 Pazar 02 & V.labrusca & $7^{\mathrm{h}-\mathrm{j}}$ & $\mathrm{R}$ & $26^{\mathrm{c}-\mathrm{i}}$ & $\mathrm{S}$ \\
\hline 55 Çarşamba 01 & V.labrusca & $21^{\mathrm{eg}}$ & $\mathrm{R}$ & $23^{\mathrm{d}-\mathrm{j}}$ & $\mathrm{R}$ \\
\hline 28 Tirebolu 02 & V.labrusca & $12^{g-j}$ & $\mathrm{R}$ & $21^{\mathrm{d}-\mathrm{k}}$ & $\mathrm{R}$ \\
\hline 28 Görele 01 & V.labrusca & $5^{\mathrm{h}-\mathrm{j}}$ & HR & $8^{i-1}$ & $\mathrm{R}$ \\
\hline 28 Merkez 01 & V.labrusca & $2^{\mathrm{ij}}$ & $\mathrm{HR}$ & $18^{\mathrm{f}-\mathrm{l}}$ & $\mathrm{R}$ \\
\hline 55 Merkez 09 & V.labrusca & $11^{\mathrm{g}-\mathrm{j}}$ & $\mathrm{R}$ & $0^{1}$ & ER \\
\hline 57 Gerze 01 & V.labrusca & $16^{\mathrm{g}-\mathrm{i}}$ & $\mathrm{R}$ & $0^{1}$ & ER \\
\hline 57 Merkez 07 & V.labrusca & $19^{\mathrm{f}-\mathrm{h}}$ & $\mathrm{R}$ & $0^{1}$ & ER \\
\hline Isabella(Yalova) & V.labrusca & $1^{\mathrm{ij}}$ & HR & $21^{\mathrm{d}-\mathrm{k}}$ & $\mathrm{R}$ \\
\hline Isabella(Tekirdağ) & V.labrusca & $11^{\mathrm{g}-\mathrm{j}}$ & $\mathrm{R}$ & $13^{\mathrm{f}-1}$ & $\mathrm{R}$ \\
\hline Steuben & Interspecific cross & $39^{\mathrm{cd}}$ & S & $40^{\mathrm{b}-\mathrm{d}}$ & $\mathrm{S}$ \\
\hline Kyoho & Interspecific cross & $9^{g-j}$ & $\mathrm{R}$ & $14^{\mathrm{f}-1}$ & $\mathrm{R}$ \\
\hline Edelweiss & Interspecific cross & $60^{\mathrm{ab}}$ & HS & $30^{\mathrm{b}-\mathrm{g}}$ & $\mathrm{S}$ \\
\hline Sheridan & Interspecific cross & $51^{\mathrm{a}-\mathrm{c}}$ & HS & $48^{\mathrm{ab}}$ & $\mathrm{S}$ \\
\hline Glenora (Seedless) & Interspecific cross & $41^{\mathrm{cd}}$ & S & $43^{\mathrm{bc}}$ & $\mathrm{S}$ \\
\hline Himrod (Seedless) & Interspecific cross & $16^{\mathrm{g}-\mathrm{i}}$ & $\mathrm{R}$ & $39^{\mathrm{b}-\mathrm{d}}$ & $\mathrm{S}$ \\
\hline Autumn Royal (Seedless) & Vitis vinifera & $7^{\mathrm{h}-\mathrm{j}}$ & $\mathrm{R}$ & $15^{\mathrm{f}-1}$ & $\mathrm{R}$ \\
\hline Red Globe & Vitis vinifera & $46^{\mathrm{b}-\mathrm{d}}$ & S & $24^{\mathrm{d}-\mathrm{i}}$ & $\mathrm{R}$ \\
\hline Italia & Vitis vinifera & $64^{\mathrm{a}}$ & HS & $64^{\mathrm{a}}$ & HS \\
\hline
\end{tabular}

The results were based on leaf-based assessments of natural infection and inoculation practices of both diseases. $V$. labrusca accessions found higher resistance than other species. When these cultivars analysed for natural downy mildew infection they showed between 0-25 disease severities. Nineteen cultivars/genotypes were found extremely resistance group and sixteen were found highly resistance. In general, results of the experiment indicated that $54.3 \%$ of cultivars/genotypes were extremely resistance (ER) and $45.7 \%$ showed high degree of resistance. 

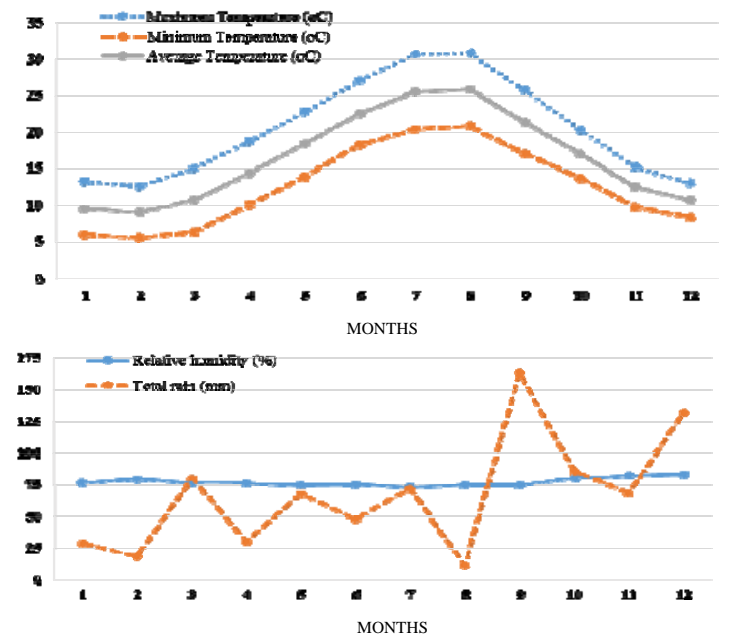

Figure 1. The main meteorologica data of experimental area in 2014.

Condições meteorológicas na área experimental em 2014.
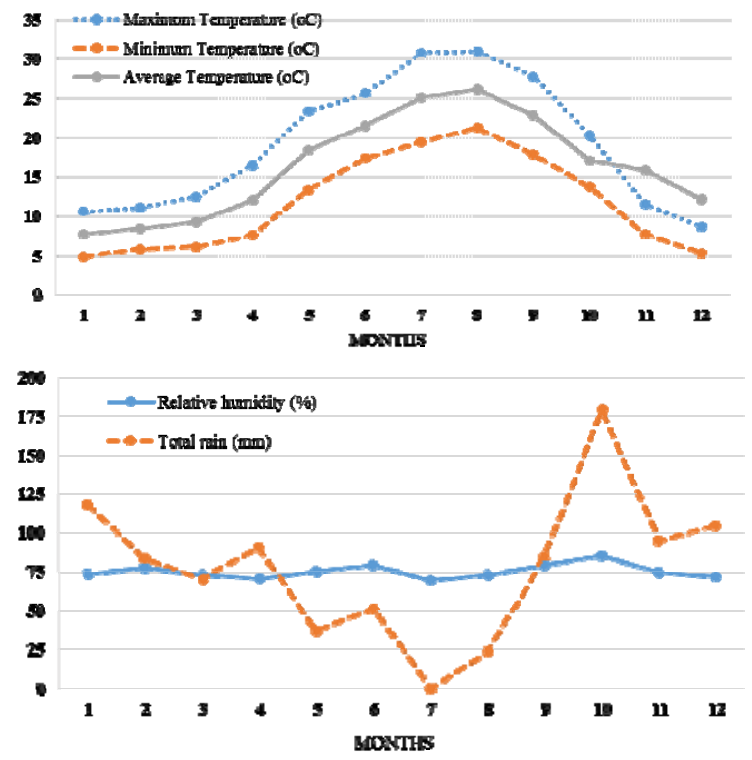

Figure 2. The main meteorological data of experimental area in 2015.

Condições meteorológicos na área experimental em 2015.

Evaluation of different cultivars/genotypes in reactions to downy mildew were obtained higher disease severity with 2-49 range. Generally, it was observed that inoculation was increased disease severity. This increase has been very evident in members of $V$. vinifera cultivars (Figure 3 and Figure 4). In a few cultivars of interspecific hybrids disease severity was significantly higher than natural infection. Highest severity of disease after natural infection was obtained in 53 Merkez 02 coded $V$. labrusca genotype. On other hand, after inoculation the highest disease severity was obtained from Vitis vinifera $c v$. Red Globe (Table III). In general, downy mildew resistant level of cultivars/genotypes found that much better than powdery mildew (Figure 4). In terms of the downy mildew evaluation of 35 cultivars/genotypes found that nine showed extremely resistant (ER), and twenty-two showed high resistance (HR) and four ranked resistant (R). Results also indicated that $25.7 \%$ of hybrids and genotypes were extremely resistance to powdery mildew, $62.9 \%$ showed high degree of resistance and $11.4 \%$ were resistant to downy mildew disease (Figure 3).
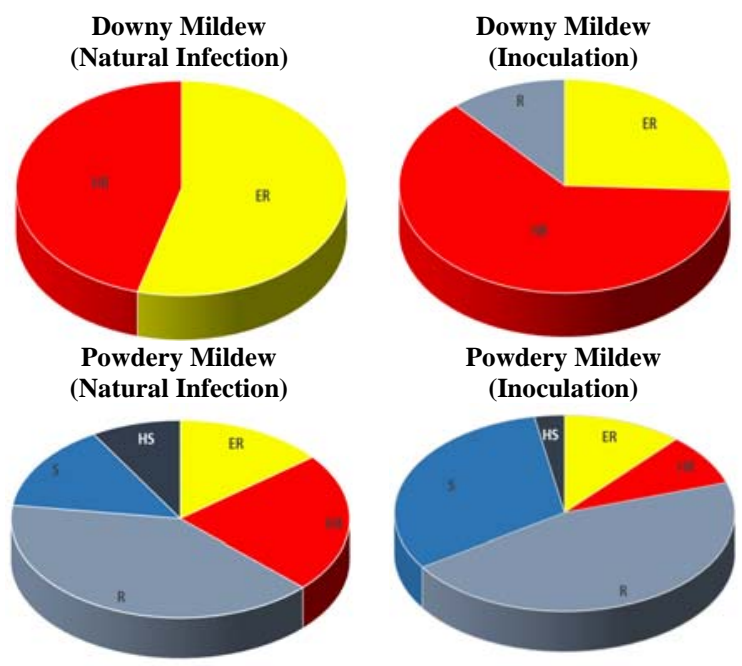

Figure 3. Distribution graph based on the number of accessions of disease severity (Extremely Resistant-ER; Highly Resistant-HR; Resistant-R; Susceptible-S; Highly susceptible-HS).

Gráfico de distribuição com base no número de acessos de severidade da doença (Extremamente Resistente-ER; Altamente Resistente-HR; Resistente-R; Suscetível-S; Altamente Suscetíveis$H S)$.

Results obtained powdery mildew evaluation also showed differences with downy mildew (Table IV). Disease severity of V.labrusca genotypes were realised respectively, after natural infection 0-33 and after inoculation 0-39 range. Overall disease severity of powdery mildew was held in the range of 0 to 64 . Unlike the downy mildew, interspecific crosses were found higher disease severity of powdery mildew (Figure 4). Highest severity of disease after natural infection and inoculation was obtained Vitis vinifera $c v$. Italia which known very sensitive for powdery mildew. Cultivars/genotypes have been identified 
more sensitivity in terms of the powdery mildew evaluation. Evaluation of different cultivars/genotypes in reactions to powdery mildew diseases under natural infection indicated that in natural field infection from among 35 cultivars/genotypes five cultivars were extremely resistance (ER) or immune, eight showed high resistance (HR), fourteen ranked resistant (R), five were susceptible (S), and finally three cultivars were high susceptible (HS) to powdery mildew causal pathogen. In this experiment cultivars/genotypes showed very different reactions to powdery mildew disease. In other words, like natural infection experiments, cultivars/genotypes ranked in five categories as extremely resistance, highly resistant, resistant, susceptible and highly susceptible. In general, results of the experiment indicated that $14.3 \%$ of hybrids and genotypes were extremely resistance to powdery mildew, $22.8 \%$ showed high degree of resistance, $40 \%$ were resistant, $14.3 \%$ were susceptible and $8.6 \%$ highly susceptible to powdery mildew disease (Figure 3).

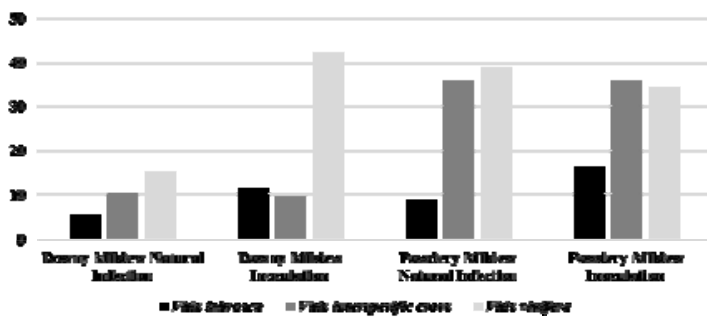

Figure 4. Average disease severity graphic of accessions.

Gráfico da severidade média da doença em $V$. labrusca, $V$. vinifera e híbridos interespecíficos.

After the inoculation of the cultivars/genotypes have been seen that increase their susceptibility to powdery mildew disease. Evaluation of different cultivars/genotypes in reactions to powdery mildew diseases under inoculation indicated that in greenhouse infection from among 35 cultivars/genotypes were classified as four extremely resistant (ER), three highly resistant (HR), sixteen resistant (R), eleven susceptible (S) and finally one highly susceptible (HS) (Table IV). Results also indicated that $11.4 \%$ of cultivars/genotypes were extremely resistance to powdery mildew, 8.6\% showed high degree of resistance, $45.7 \%$ were resistant, $31.4 \%$ were susceptible and $2.9 \%$ highly susceptible to powdery mildew disease (Figure 3).

The result of the present study shows that differences in susceptibility to downy mildew and powdery mildew exist among Vitis cultivars/genotypes, as previously reported (Staudt and Kassemeyer, 1995; Cadle-Davidson, 2008; Gee et al., 2008). Differences in susceptibility were also seen between different species of Vitis, as earlier mentioned by several authors (Yu et al., 2012; Boso et al., 2014). Figueiredo et al. (2017) explained that following inoculation increase of hydrogen peroxide levels, cellular redox regulation, establishment of ROS signalling and plant cell death seem to be key points differentiating the resistant genotype. Lipid associated signalling events, particularly related to jasmonates appear also to play a major role in the establishment of resistance. The findings from this study also can explain this pathways contribute to a better understanding of genotype-specific differences that account for a successful establishment of a defence response to disease pathogens. Furthermore, Oliveira and Cunha (2015) reported that diversity of these pathogens also can affect disease resistance of Vitis spp.

Susceptibility of $V$. labrusca cultivars studied very limited numbers and these studies have highlighted that there may be differences between the cultivars (Cadle-Davidson, 2008; Gee et al., 2008; Wu et al., 2011). It is reported that even different ecology also affect resistance to powdery mildew disease (CadleDavidson et al., 2011). Similar results were obtained in this study and some cultivars/genotypes came forward as more resistant. Vitis labrusca genotypes which are 55 Merkez 09, 57 Gerze 01 and 57 Merkez 07 were selected the most resistance genotypes when evaluated both diseases in this study. Addition to these genotypes, 55 Merkez 12, 55 Merkez 06 and 61 Sürmene 02 genotypes showed high resistant against powdery mildew. Also Ülkemiz, 28 Görele 01 and 57 Erfelek 03 genotypes showed high resistant against downy mildew.

In a similar way sensitivity of powdery mildew in interspecific crosses were higher. Similar results also were obtained in the Glenora and Himrod seedless cultivars. They were much more affected by powdery mildew disease. However, Vitis vinifera $c v$. Autumn Royal which are also seedless much more affected by downy mildew disease but not powdery mildew. Sha et al. (2007), similarly reported that Autumn Royal cultivar resistant to powdery mildew disease but other seedless cultivars are susceptible. The same authors also similarly reported that tetraploid Kyoho cultivar are resistant to powdery mildew.

The highest sensitivity was observed in V.vinifera cultivars with few exceptions. Vitis vinifera $c v$. Italia showed low resistance than other cultivars as expected but especially much more affected by 
powdery mildew. Red Globe cultivar showed lower resistance to downy and powdery mildew. Wu et al. (2011), also found that Red Globe have high susceptibility both diseases furthermore they reported that the hybrids derived from V.labrusca have a higher resistance.

In addition to these analyzes, correlation analysis was used to explore the relationships between the variables (Table V). There was a significant correlation between the natural infection and inoculation of both diseases. The significant positive correlation was found between powdery mildew natural infection and inoculation (0.602). Similarly, there was a found significant positive correlation between downy mildew natural infection and inoculation (0.486). This analysis suggests that powdery mildew disease is more effective on cultivars or genotypes.

Table V

Pearson correlation coefficients (R) between variables

Coeficientes de correlação de Pearson (R) entre variáveis

\begin{tabular}{|c|c|c|c|c|}
\hline Variables & $\begin{array}{c}\text { Downy Mildew } \\
\text { (Natural Infection) }\end{array}$ & $\begin{array}{c}\text { Downy Mildew } \\
\text { (Inoculation) }\end{array}$ & $\begin{array}{c}\text { Powdery Mildew } \\
\text { (Natural Infection) }\end{array}$ & $\begin{array}{c}\text { Powdery Mildew } \\
\text { (Inoculation) }\end{array}$ \\
\hline Downy Mildew (Natural Infection) & 1 & 0.486 & 0.285 & 0.442 \\
\hline Downy Mildew (Inoculation) & 0.486 & 1 & 0.163 & 0.193 \\
\hline Powdery Mildew (Natural Infection) & 0.285 & 0.163 & 1 & $0.602 *$ \\
\hline Powdery Mildew (Inoculation) & 0.442 & 0.193 & $0.602 *$ & 1 \\
\hline
\end{tabular}

Powdery mildew and downy mildew in terms of the sensitivity of selected cultivars/genotypes were different. Especially it was realised that downy mildew resistance of cultivars/genotypes was higher than resistance of powdery mildew. Different types of resistance in Vitis spp. have been identified. Similar results are obtained with different species and cultivars by several studies. In general, $V$. vinifera cultivars have lower disease resistant but $V$. labrusca and other Vitis spp. have better disease resistant when compared species, especially some $V$. labrusca genotypes unexpectedly found low disease resistant. It is thought to be caused by parents and also reported that some species and cultivars can have different resistant levels in several studies. Variation, also been recorded between different cultivars of $V$. vinifera, and even between clones of the same variety (Boso et al., 2006; Khiavi et al., 2009; Alonso-Villaverde et al., 2011; Yu et al., 2012; Gaforio et al., 2015). This variability in susceptibility may have several causes and mechanisms (anatomical, biochemical, molecular, etc.). Alonso-Villaverde et al. (2011) and Gindro et al. (2006) indicated that such differences among $V$. vinifera cultivars may be due to certain anatomical or histological features of the leaf structure. In recent years, researchers have also determined different genes which are responsible for downy and powdery mildew in different Vitis species.
Pap et al. (2016) reported that two distinct powdery mildew R loci designated Ren6 and Ren7 were found in multiple accessions from the Chinese species $V$. piasezkii. Also some QTLs with major DM-resistance effects have been identified, named Rpv (Resistance to $P$. viticola). New Rpv regions have been found on different chromosome numbers (Blasi et al., 2011; Schwander et al., 2012; Venuti et al., 2013; Armijo et al., 2016). As can be clearly seen in this study, cultivars or genotypes can have different resistant level even if they belong to the same species. Even some of them have gene regions that are responsible for the resistance, they may not be sufficient for enough disease resistance. Plant defense mechanisms are tightly regulated by hormone-mediated signaling pathways, mainly jasmonic acid (JA) and salicylic acid (SA). It is generally considered that JA and ethylene (JA/Et) mediate necrotrophic pathogens defense, while SA is involved against the biotrophic and hemibiotrophic ones (Pieterse et al., 2009; Robert-Seilaniantz et al., 2011).

\section{CONCLUSIONS}

Researches on the causes and mechanisms of resistance or susceptibility to diseases in plants have been going on for many years. Almost every year new gene regions and different biochemicals that are 
effective on resistance are found by scientists. Different breeding studies transfering these genes to sensitive cultivars are still continue. However, the cultivars or genotypes carrying theseresistant gene regions should primarily be determined as in this study. As a result of this study carried out for this main purpose some $V$. labrusca genotypes were selected the more resistance than other Vitis spp. when evaluated downy and powdery mildew diseases. They can be used as parents for transferring downy and powdery mildew resistance genes. In other words, they have potential as a breeding line for the future improvement of disease resistance. These genotypes will be very useful for future breeding programmes to obtain new cultivars with high resistance levels. Resistant lines are particularly valuable for breeding programmes when used to transfer multiple resistance genes into high yield. Also as results of this study may have practical applications in formulation of disease management

\section{REFERENCES}

Alonso-Villaverde V., Boso S., Santiago J.L., Gago P., RodriguezGarcía M.I., Martínez M.C., 2011. Leaf thickness and structure of Vitis vinifera cv. Albariño clones and its possible relation with downy mildew (Plasmopara viticola) infection. J. Int. Sci. Vigne Vin, 45,161-169.

Armijo G., Schlechter R., Agurto M., Muñoz D., Nuñez C., ArceJohnson P., 2016. Grapevine pathogenic microorganisms: understanding infection strategies and host response scenarios. Front. Plant Sci., 7:382.

Blasi P., Blanc S., Wiedemann-Merdinoglu S., Prado E., Ruhl E.H., Mestre P., Merdinoglu D., 2011. Construction of a reference linkage map of Vitis amurensis and genetic mapping of Rpv8, a locus conferring resistance to grapevine downy mildew. Theor. Appl. Genet., 123, 43-53.

Boso S., Alonso-Villaverde V., Gago P., Santiago J.L., Martínez M.C., 2014. Susceptibility to downy mildew (Plasmopara viticola) of different Vitis cultivars. Crop Protec., 63, 26-35.

Boso S., Martínez M.C., Unger S., Kassemeyer H.H., 2006. Evaluation of foliar resistance to downy mildew in different cv. Albariño clones. Vitis, 4, 23-27.

Cadle-Davidson L., 2008. Variation within and between Vitis spp. for foliar resistance to the downy mildew pathogen Plasmopara viticola. Plant Dis., 92, 1577-1584.

Cadle-Davidson L., Chicoine D.R., Consolie N.H., 2011. Variation within and among Vitis spp. for foliar resistance to the powdery mildew pathogen Erysiphe necator. Plant Disease, 95, 202-211.

Carisse O., Bacon R.L., McFadden-Smith W., 2006. Identification guide to the major diseases of grapes. Agriculture and Agri-Food, 31 p. Canada Publication 10092.

Cindric P., Korac N., Kovac V., 2009. Grape breeding for fungal resistance using North American and Asian donor genotypes. Acta Hort., 827, 631-634.

Deliere L., Miclot A.S., Sauris P., Rey P., Calonnec A., 2010. Efficacy of fungicides with various modes of action in controlling strategies for controlling both diseases in a safe environment. The use of resistant hybrids or genotypes to manage different plant diseases including grape downy and powdery mildew can potentially replace or minimize the application of harmful chemical fungicides. Also they could be used as an important component of Integrated Pest Management Programmes which is a very useful approach to a sustainable and also maybe organic agriculture.

\section{ACKNOWLEDGMENTS}

This research was funded by the National Scientific and Technological Research Council of Turkey (Grant No.1130641).

the early stages of an Erysiphe necator-induced epidemic. Pest Manag. Sci., 66, 1367-1373.

FAO, 2015. Production of grape. Available at: http://faostat.fao.org/site/339/default.aspx. Accessed 2015 November 20.

Figueiredo A., Martins J., Sebastiana M., Guerreiro A., Silva A., Matos A.R., Monteiro F., Pais M.S., Roepstorff P., Coelho A.V., 2017. Specific adjustments in grapevine leaf proteome discriminating resistant and susceptible grapevine genotypes to Plasmopara viticola. J. Proteomics, 152, 48-57.

Gaforio L., Cabello F., Organero G.M., 2015. Evaluation of resistance to downy mildew in grape cultivars grown in a Spanish collection. Vitis, 54, 197-191.

Gee C.T., Cadle-Davidson L., Gadoury D.M., 2008. Ontogenetic resistance to Uncinula necator varies by genotype and tissue type in a diverse coleciton of Vitis spp. Plant Dis., 92, 1067-1073.

GENRES-081 1997. Descriptors for grapevines (Vitis spp.). International Union for the Protection of New Cultivars of Plants, Geneva, Switzerland/Office International de la Vigne et du Vin, Paris, France/International Plant Genetic Resources Institute, Rome, Italy.

Gindro K., Spring J.L., Pezet R., Richter J., Viret O., 2006. Histological and biochemical criteria for objective and early selection of grapevine cultivars resistant to Plasmopara viticola. Vitis, 45, 191-196.

Hajdu E., 2007. Breeding of table grape cultivars in Hungary and beyond our national borders. Hung. Agric. Res., 4, 4-9.

Hoffmann S., Cindric P., Kozma P.Jr., 2007. Breeding resistant cultivars to downy and powdery mildew. XXX. World Congress of Vine and Wine. http://www.oiv2007.hu/documents/viticulture/314_breeding_resista nte_cultivars_to_1_.pdf .

Khiavi H.K., Shikhlinski H., Ahari A.B., Heydari A., 2009. Evaluation of different grape cultivars for resistance to powdery mildew caused by Uncinula necator. J. Plant Prot. Res., 49, 434440 . 
Lisek J., 2014. Evaluation of yield and healthiness of twenty table grapevine cultivars grown in Central Poland. J. Horti. Res., 22, 101-107.

Oliveira M., Cunha M., 2015. Study of the Portuguese populations of powdery mildew fungus from diverse grapevine cultivars (Vitis vinifera). OENO One, 49, 173-182.

Pap D., Riaz S., Dry I.B., Jermakow A,, Tenscher A. C., Cantu D., Oláh R., Walker M. A., 2016. Identification of two novel powdery mildew resistance loci, Ren6 and Ren7, from the wild Chinese grape species Vitis piasezkii. BMC Plant Biol., 16, 170.

Pieterse C.M., Leon-Reyes A., VanderEnt S., Van Wees S. C., 2009. Networking by small-molecule hormones in plant immunity. Nat. Chem. Biol., 5, 308-316.

Riaz S., Tenscher A.C., Ramming D.W., Walker M.A., 2011. Using a limited mapping strategy to identify major QTLs for resistance to grapevine powdery mildew (Erysiphe necator) and their use in marker-assisted breeding. Theor. Appl. Genet., 122, 1059-1073.

Robert-Seilaniantz A., Grant M., Jones J.D., 2011.Hormone cross talk in plant disease and defense: more than just jasmonatesalicylate antagonism. Annu. Rev. Phytopathol., 49, 317-343.

Rumbolz J., Wirtz S., Kassemeyer H.H., Guggenheim R., Schäfer E., Büche C., 2002. Sporulation of Plasmopara viticola: differentiation and light regulation. Plant Biol., 4, 413-422.

SAS, 2007. JMP statistical discovery software. JMP 7.0 Edition of programme. SAS Institute Inc Cary, North Carolina, USA.

Schwander F., Eibach R., Fechter I., Hausmann L., Zyprian E., Topfer R., 2012. Rpv10: a new locus from the Asian Vitis gene poolforpyramiding downy mildew resistance loci in grapevine. Theor. Appl. Genet., 124, 163-176.
Sha Y., Wang G., Fan Z., Zhang Y., Zhang X., 2007. Study on the resistance of different grape cultivars to downy mildew. J. Fruit Sci., 24, 803-809.

Staudt G., Kassemeyer H.H., 1995. Evaluation of downy mildew (Plasmopara viticola) resistance in various accessions of wild Vitis species. Vitis, 34, 225-228.

Townsend G.R., Heuberger J.W., 1943. Methods for estimating losses caused by diseases in fungicide experiments. Plant Dis. Rep., 27, 340-343.

TUIK, 2015. Production of Fruits; Beverage and Spice Crops (For Selected Products). http://www.turkstat.gov.tr/UstMenu.do?metod=temelist. Accessed 2015 November 20

Venuti S., Copetti D., Foria S., Falginella L., Hoffmann S., Bellin D., Cindric P., Kozma P., Scalabrin S., Morgante M., Testolin R., Gaspero G., 2013. Historical introgression of the downy mildew resistance gene Rpv 12 from the Asian species Vitis amurensis into grape vine varieties. Plos One, 8, e61228.

Wan Y., Schwaninger H., He P., Wang Y., 2007. Comparison of resistance to powdery mildew and downy mildew in Chinese wild grapes. Vitis, 46, 132-136.

Wang Y., Li Y., He P., Chen J., Lamikanra O., Lu J., 1995. Evaluation of foliar resistance to Uncinula necator in Chinese wild Vitis species. Vitis, 34, 159-164.

Wu X., Liu N., Zhang J., Wang Y., 2011. Field natural identification of resistance of grape resources from USA and Xinjiang of China to primary fungi diseases. J. Fruit Sci, 28, 9981009.

Yu Y., Zhang F., Yin L., Lu J., 2012. The mode of host resistance to Plasmopara viticola infection on grapevines (Vitis L). Phytopathology, 102, 1094-1101. 